\title{
PERBANDINGAN KEMAMPUAN PEMECAHAN MASALAH MATEMATIS SISWA YANG BELAJAR MENGGUNAKAN MODEL PEMBELAJARAN KOOPERATIF TIPE THINK TALK WRITE DAN THINK PAIR SHARE DI SMP NEGERI 1 TANJUNG MORAWA
}

\author{
${ }^{1}$ Rahmadhani Siregar, ${ }^{2}$ Syafari \\ ${ }^{1}$ Fakultas Matematika dan Ilmu Pengetahuan Alam, Universitas Negeri Medan \\ ${ }^{2}$ Dosen Fakultas Matematika dan Ilmu Pengetahuan Alam, Universitas Negeri Medan \\ Email: Rahmadhanisiregar@yahoo.com
}

\begin{abstract}
ABSTRAK
Penelitian ini bertujuan untuk melihat bahwa kemampuan pemecahan masalah matematika menggunakan model pembelajaran TTW lebih tinggi daripada model pembelajaran TPS pada materi Bangun Datar di kelas VII SMP Negeri 1 Tanjung Morawa. Jenis penelitian ini adalah eksperimen semu. Populasi dalam penelitian ini adalah seluruh siswa kelas VII yang terdiri dari 7 kelas dengan jumlah keseluruhan siswa 201 orang. Pengambilan sampel dilakukan dengan cara cluster random sampling dengan mengambil 2 kelas dari 7 kelas secara acak yaitu kelas eksperimen A yang berjumlah 25 orang dan kelas eksperimen 2 yang berjumlah 26 orang. Instrumen yang digunakan untuk mengetahui kemampuan pemecahan masalah matematika siswa adalah tes kemampuan pemecahan masalah yang telah divalidasi dalam bentuk uraian. Dari hasil penelitian yang diberikan perlakuan yang berbeda, kelas eksperimen A dengan model pembelajaran TTW dan kelas eksperimen B dengan model pembelajaran TPS diperoleh nilai rata-rata kelas eksperimen A sebesar 28,20 dan nilai rata-rata kelas eksperimen $B$ sebesar 25,27. Hasil uji $t$ pihak kanan dengan $d k=49$ dan $\alpha$ $=0,05$, diperoleh $t_{\text {hitung }}=3,66$ dan $t_{\text {tabel }}=1,6655$ sehingga $t_{\text {hitung }}>t_{\text {tabel }}$ yaitu 3,66 > 1,6655 maka Ha diterima, dengan demikian diperoleh kesimpulan bahwa kemampuan pemecahan masalah matematika menggunakan model pembelajaran TTW lebih tinggi dari model pembelajaran TPS pada materi bangun datar.
\end{abstract}

Kata Kunci : Model pembelajaran Think Talk Write dan Think Pair Share, Pemecahan Masalah Matematika

\begin{abstract}
This study aims to see that the ability to solve mathematical problems using the TTW learning model is higher than the model of TPS learning in Building materials in Class VII SMP Negeri 1 Tanjung Morawa. This type of research is a quasi experiment. The population in this study is all students of class VII consisting of 7 classes with total students 201 people. Sampling was done by cluster random sampling by taking 2 classes from 7 classes randomly that is experiment class $A$ which amounted to 25 people and experiment class 2 which amounted to 26 people. The instrument used to determine students' mathematical problem solving abilities is a validated problem-solving test in the form of a description. From the result of the research given different treatment, experiment class A with TTW learning model and experiment class B with TPS learning model obtained the average value of experiment class $A$ of 28.20 and the average value of experimental class $B$ is 25.27. The result of right side $t$ test with $d k=49$ and $\square=0,05$,
\end{abstract}

Rahmadhani Siregar, Syafari. Perbandingan Kemampuan Pemecahan Masalah Matematis Siswa yang Belajar Menggunakan Model Pembelajaran Kooperatif Tipe Think Talk Write dan Think Pair Share di SMP Negeri 1 Tanjung Morawa. Jurnal Inspiratif, Vol 3. No. 1 April 2017 
obtained tcount $=3,66$ and ttable $=1,6655$ so thitung $>$ table that is 3,66>1,6655 then Ha accepted, thus obtained conclusion that ability Mathematical problem solving using TTW learning model is higher than the model of TPS learning in flat matter.

Keywords: Think Talk Write and Think Pair Share Learning Model, Mathematical Problem Solving

\section{Pendahuluan}

Pendidikan merupakan hal yang sangat penting bagi manusia, karena pendidikan merupakan investasi sumber daya manusia dalam jangka panjang. Pendidikan juga merupakan wahana untuk meningkatkan dan mengembangkan kualitas sumber daya manusia. Perkembangan dunia pendidikan yang semakin pesat, menuntut lembaga pendidikan untuk bekerja lebih baik dalam menyesuaikan perkembangan ilmu pengetahuan dengan pendidikan yang ada di negara kita. Kegiatan proses belajar mengajar merupakan kegiatan inti dalam upaya meningkatkan kualitas pendidikan. Baik buruknya suatu proses pembelajaran adalah salah satu faktor dominan dalam menentukan kualitas pendidikan.

Matematika sebagai salah satu pengetahuan mendasar yang sangat penting dan sangat dibutuhkan dalam perkembangan teknologi saat ini, dimana tujuan pembelajaran matematika dalam BSNP (dalam Wicaksana, 2014) :

1. Melatih cara berpikir dalam bernalar atau menarik kesimpulan, misalnya melalui kegiatan penyelidikan, eksplorasi, eksperimen, menunjukkan kesamaan, perbedaan, konsistens, dan inkonsistens.

2. Mengembangkan aktifitas yang menyebabkan imajinasi, intuisi, dan penemuan, mengembangkan pemikiran divergen orisinal, rasa ingin tahu, membuat prediksi, dan dugaan sementara serta mencobacoba.

3. Mengembangkan kemampuan memecahkan masalah.

4. Mengembangkan kemampuan menyampaikan informasi atau mengkomunikasikan gagasan antara lain melalui pembicaraan lisan, catatan, grafik, peta, diagram dalam menjelaskan.

Sejalan dengan pendapat di atas, belajar matematika diharapkan dapat meningkatkan kemampuan berpikir, bernalar, mengkomunikasikan gagasan serta dapat meningkatkan aktifitas kreatif dan pemecahan masalah. Ini menunjukkan bahwa matematika memiliki manfaat dalam mengembangkan kemampuan siswa sehingga perlu untuk dipelajari. Muller dan Burkhardt (2007:1) mengatakan bahwa "Matematika merupakan salah satu bagian terpenting dalam kurikulum setiap Negara, terutama karena matematika memiliki peran yang sangat penting dalam kehidupan, pekerjaan, dan digunakan juga untuk memecahkan masalah yang ada di mata pelajaran lain".

Oleh karena itu, kualitas pendidikan matematika di Indonesia hendaknya ditingkatksan seiring dengan perkembangan zaman. Karena pada kenyataannya sampai saat ini kualitas pendidikan di Indonesia masih sangat rendah jika dibandingkan dengan negara lain, 
terutama pada bidang studi matematika. Hasil studi Programme for International Student Assessment (PISA) $2012 \quad$ (dalam Metrotvnews.com, 2013) menunjukkan sistem pendidikan Indonesia masih sangat rendah.

Dari 65 negara anggota PISA, pendidikan Indonesia berada di bawah peringkat 64. Untuk literasi matematika, pelajar Indonesia berada di peringkat 64 dengan skor 375 . Adapun skor literasi sains berada di peringkat 64 dengan skor 382 .

\section{Salah satu fokus} pembelajaran matematika saat ini adalah meningkatkan kemampuan pemecahan masalah matematika siswa melalui pembelajaran yang berawal dari suatu pengalaman siswa yang terjadi dalam kehidupan seharihari. Dengan pembelajaran melalui pengalaman siswa yang terjadi dalam kehidupan sehari-hari maka akan membuat siswa lebih memahami dan mengigat konsep yang mereka pelajari. Rosli dkk (2013:54) berpendapat bahwa "Pemecahan masalah dan telah menjadi kegiatan kognitif yang penting dalam proses belajar mengajar matematika". Selain itu Sumiati dan Asra (2013:89) mengemukakan bahwa :

"Pemecahan masalah banyak menunjang kreativitas seseorang, yaitu kemampuan menciptakan ide baru, baik yang bersifat asli ciptaanya sendiri, maupun merupakan suatu modifikasi (perubahan) dari berbagai ide yag telah ada sebelumnya.

Pemecahan masalah merupakan proses menerapkan pengetahuan yang telah diperoleh sebelumnya ke dalam situasi baru yang belum dikenal. Metode pemecahan masalah adalah suatu cara pembelajaran dengan menghadapkan siswa kepada suatu masalah untuk dipecahkan atau diselesaikan. Menurut Sanjaya (2009:219) "Pemecahan masalah dapat mengembangkan kemampuan siswa untuk berfikir kritis dan mengembangkan kemampuan mereka untuk menyesuaikan dengan pengetahuan yang baru.

$$
\text { Problem }
$$

Solving

(Kemampuan Pemecahan Masalah) dalam matematika menurut Charles dan Lester (1982:23) merupakan hal terpenting dalam matematika, dimana Problem Solving adalah strategi yang sering digunakan orang dalam proses pemecahan masalah. Pemecahan masalah dalam pembelajaran matematika merupakan pendekatan dan tujuan yang harus dicapai. Pemecahan masalah sebagai pendekatan digunakan untuk menemukan dan memahami materi atau konsep matematika.

Menurut Zulkarnain (2015:102) prestasi belajar siswa di matematika dapat dilihat dari kemampuan mereka dalam menyelesaikan pertanyaan matematika yang terdiri dari pertanyaan non cerita dan pertanyaan cerita. Dalam rangka meningkatkan hasil belajar siswa khusunya pelajaran matematika, diperlukan kemampuan pemecahan masalah sehingga siswa lebih mengetahui tentang keterkaitan ilmu yang dipelajari dengan kegiatan swhariharinya. Implikasinya, hasil belajar siswa akan jauh lebih baik apabila siswa sering dihadapkan pada suatu masalah. Pemecahan masalah merupakan hal yang sangat penting dalam pembelajaran matematika. Sehingga hampir di semua standar kompetensi dan kompetensi dasar

Rahmadhani Siregar, Syafari. Perbandingan Kemampuan Pemecahan Masalah Matematis Siswa yang Belajar Menggunakan Model Pembelajaran Kooperatif Tipe Think Talk Write dan Think Pair Share di SMP Negeri 1 Tanjung Morawa. Jurnal Inspiratif, Vol 3. No. 1 April 2017 
dijumpai penegasan diperlukannya kemampuan pemecahan masalah (Syaiful, 2012:37)

Dengan demikian, kemampuan pemecahan masalah menjadi salah satu kegiatan yang penting untuk dilaksananakan dalam kegiatan belajar-mengajar di sekolah. Yang menjadi masalah adalah bagaimana kemampuan pemecahan masalah itu dilaksanakan dengan efisien dalam kegiatan belajar mengajar matematika. Keterampilan memecahkan masalah harus dimiliki oleh siswa dan keterampilan ini akan dimiliki siswa apabila guru mengajarkan dan menstimulus kemampuan siswa untuk dapat menyelesaikan masalah dalam pembelajaran matematika.

Tetapi pada kenyataanya, banyak siswa yang mengalami kesulitan dalam memecahkan masalah matematika. Siswa selalu mengalami kesulitan dalam menyelesaikan soal yang berkaitan dengan pemecahan masalah terutama soal yang berhubungan dengan soal cerita. Kesulitan terletak pada siswa untuk merepresentasikan kalimat pada soal kedalam kalimat matematika. Terkadang siswa dapat menjawab soal matematika tanpa memperhatikan proses untuk mendapatkan jawaban tersebut. Hal ini menyebabkan siswa mengalami kesulitan belajar matematika yang mengakibatkan kemampuan pemecahan masalah siswa rendah. Siswa lebih sering dan suka mencatat atau menghafal konsep matematika , meskipun mereka tidak memahami apa yang mereka hapal dan catat. Hal seperti ini menyebabkan ketika sewaktu-waktu siswa diberi masalah matematika dan diminta untuk menyelesaikannya dengan proses yang terstruktur, mereka tidak memahami masalah dan tidak mampu menggunakan strategi yang akan digunakan untuk menyelesaikan permasalahan yang telah diberikan.

Hal ini didukung dari hasil observasi awal peneliti yaitu hasil wawancara dengan ibu Riswati, S.Pd juga mengatakan hal yang sama yakni:

Terkait dengan soal yang berhubungan dengan masalah seharihari, siswa kurang mampu dalam memecahkan soal. Siswa lebih mudah menyelesaikan soal yang bentuk soalnya sama dengan contoh soal yang sudah di jelaskan sebelumnya.

Selanjutnya peneliti memberikan tes kepada 35 siswa SMP Negeri 1 Tanjung Morawa dalam bentuk soal uraian. Soal yang digunakan yaitu:

1. Ayah ingin memasang pagar mengelilingi kebun pisang dengan kawat duri agar daun dan pisang yang ada di kebunnya tidak dimakan oleh kambing. Apabila kebun ayah berbentuk persegi panjang dengan panjang $20 \mathrm{~m}$ dan lebar $10 \mathrm{~m}$. Berapakah panjang kawat duri yang harus di siapkan ?

Apa yang diketahui dan ditanyakan dari soal tersebut?

Jelaskan rencana yang kamu gunakan untuk menghitung panjang kawat duri yang harus disiapkan

Berdasarkan langkah ke-2, gunakan rencana yang kamu buat untuk menghitung panjang kawat duri yang harus disiapkan

Periksalah jawaban anda dengan menggunakan data yang ada pada masalah tersebut! Berikan kesimpulan! 
2. Budi memiliki sebidang tanah berbentuk persegi panjang yang ditanami pohon kelapa dengan luas $143 \mathrm{~m}^{2}$ dan lebarnya 11 meter. Berapakah panjang kebun pohon kelapa budi ?

Apa yang diketahui dan ditanya soal tersebut?

Jelaskan rencana yang kamu gunakan untuk menyelesaikan panjang kebun pohon kelapa adi?

Berdasarkan langkah ke-2, gunakan rencana yang kamu buat untuk mengetahui panjang kebun pohon kelapa budi?

Periksalah jawaban anda dengan menggunakan data yang ada pada masalah tersebut! Berikan kesimpulan!

3. Paman memiliki kayu bingkai sepanjang $200 \mathrm{~cm}$. Paman berencana membuat sebuah bingkai foto berbentuk persegi

Berdasarkan hasil tes yang diberikan, dari 34 orang siswa diperoleh data yaitu $28,95 \%$ (10 orang) siswa yang mampu menyelesaikan masalah dan 71,05 (25 orang) siswa tidak mampu menyelesaikan masalah sesuai indikator pemecahan masalah. Pada indikator memahami masalah, secara umum kesalahan siswa terletak pada sulitnya siswa mengidentifikasi apa yang diketahui dan yang ditanyakan dalam soal tersebut, yaitu $42,10 \%$ (16 orang) yang mampu memahami masalah. Pada indikator menyusun rencana penyelesaian, secara umum kesalahan siswa terletak pada pengaplikasian dari apa yang diketahui dan yang ditanyakan dalam soal tersebut, yaitu $18,42 \%$ (6 orang) yang mampu menyusun rencana dengan panjang sisi $40 \mathrm{~cm}$. Berapakah panjang kayu bingkai yang di perlukan untuk membuat bingkai foto dan sisa kayu bingkai?

Apa yang diketahui dan ditanya soal tersebut?

Jelaskan rencana yang kamu gunakan untuk menyelesaikan persoalan tersebut?

Berdasarkan langkah ke-2, gunakan rencana yang kamu buat untuk mengetahui panjang kayu bingkai yang di perlukan dan sisa kayu bingkai?

Periksalah jawaban anda dengan menggunakan data yang ada pada masalah tersebut! Berikan kesimpulan!

Berikut adalah hasil pengerjaan beberapa siswa yang melakukan kesalahan dalam menyelesaiakan soal uraian di atas, seperti pada tabel 1.1

penyelesaian. Pada indikator memeriksa kembali hanya $31,57 \%$ (12 orang) yang melakukan pemeriksaan terhadap jawaban yang diperoleh. Dari data tersebut dapat diketahui bahwa kemampuan pemecahan masalah matematika siswa masih rendah.

Melihat kondisi diatas, maka diperlukan suatu model pembelajaran yang dapat memfasilitasi kebutuhan proses kegiatan belajar mengajar yang melatih kemampuan pemecahan masalah matematika siswa. Peneliti mengasumsikan dengan menerapkan model pembelajaran kooperatif dapat meningkatkan kemampuan pemecahan masalah matematika siswa. Hal ini disebabkan bahwa 
model pembelajaran kooperatif merupakan model belajar yang melibatkan beberapa siswa untuk bekerja secara berkelompok untuk memperoleh tujuan yang sama dan berpartisipasi untuk bekerja bersama serta saling berinteraksi sehingga mampu meningkatkan kemampuan pemecahan masalah matematika siswa. Hal ini didukung oleh pendapat ahli seperti pendapat Nurulhayati (Rusman, 2014 : 203), "Pembelajaran kooperatif adalah strategi pembelajaran yang melibatkan partisispasi siswa dalam satu kelompok kecil untuk saling berinteraksi”. Model pembelajaran kooperatif juga menyajikan pembelajaran yang berpusat pada siswa sehingga siswa terlibat langsung dalam menyelesaikan masalah yang ada.

Zakaria et al. (2010) menyatakan bahwa pembelajaran kooperatif merupakan pendekatan yang efektif, yang guru matematika perlu memasukkan dalam pengajaran mereka. Pembelajaran kooperatif adalah sebuah proses pembelajaran yang melibatkan siswa dalam pembelajaran, dimana siswa dilatih untuk bisa dan mau bekerja sama dalam kelompok-kelompok kecil untuk mencapai tujuan bersama. Misalnya dengan menggunakan model pembelajaran Think Pair Share (TPS) dan model pembelajaran Think Talk Write (TTW). Model pembelajaran TPS dan TTW merupakan model pembelajaran yang sama sama bertujuan untuk meningkatkan daya tarik siswa dalam pemecahan masalah.

Model pembelajaran kooperatif tipe Think-pair-share (TPS) pertama kali dikembangkan oleh Frank Lyman dan koleganya di Universitas
Maryland. Menurut Arends (dalam Ansari, 2009) menyatakan bahwa:

Think Pair Share (TPS) merupakan suatu cara yang efektif untuk mengganti pola diskusi kelas. Dengan asumsi bahwa semua resitasi atau diskusi membutuhkan penganturan untuk mengendalikan kelas secara keseluruhan, dan prosedur yang digunakan dalam think pair share dapat memberi siswa lebih banyak waktu untuk berpikir, untuk merespon, dan untuk saling membantu.

Seperti namanya "Thinking", pembelajaran ini diawali dengan berfikir. Guru memberikan kesempatan kepada mereka memikirkan jawabannya. Selanjutnya, "Pairing" pada tahap ini guru meminta peserta didik berpasangan-pasangan. Beri kesempatan pasangan pasangan itu untuk berdiskusi. Yang terakhir "Sharing" hasil diskusi di tiap-tiap pasangan dibicarakan dengan seluruh pasangan di dalam kelas (Istarani, 2011: 67)

Menurut pendapat Miftahul (2014 : 206) Manfaat TPS antara lain adalah:

1) Memungkinkan siswa untuk bekerja sendiri dan bekerja sama dengan orang lain

2) Mengoptimalkan partisipasi siswa

3) Memberi kesempatan kepada siswa untuk menunjukkan partisipasi mereka kepada orang lain.

Skill-skill yang umumnya dibutuhkan dalam strategi ini adalah sharing informasi, bertanya, meringkas gagasan orang lain, dan paraphrasing.

Dari pendapat di atas dapat disimpulkan bahwa waktu yang diberikan untuk berfikir, saling

Rahmadhani Siregar, Syafari. Perbandingan Kemampuan Pemecahan Masalah Matematis Siswa yang Belajar Menggunakan Model Pembelajaran Kooperatif Tipe Think Talk Write dan Think Pair Share di SMP Negeri 1 Tanjung Morawa. Jurnal Inspiratif, Vol 3. No. 1 April 2017 
berdiskusi, dan berbagi ide dalam menyelesaikan masalah memungkinkan siswa untuk lebih aktif dalam proses belajar. Melalui pembelajaran kooperatif tipe TPS ini diharapkan siswa aktif berusaha mengembangkan kemampuannya dalam berbagai ide dengan pasangannya dan seluruh pasangan yang ada di dalam kelas sehingga secara tidak langsung siswa juga akan memperoleh pemahaman yang lebih besar dalam memecahkan masalah. Hal ini juga di dukung oleh penelitian relevan yang dilakukan oleh Husna (2013) yang menyatakan bahwa peningkatan kemampuan pemecahan masalah matematis siswa yang memperoleh model pembelajaran kooperatif tipe TPS lebih baik daripada siswa yang memperoleh pembelajaran konvensional.

Model Pembelajaran

kooperatif tipe Think-Talk-Write merupakan salah satu alternatif pembelajaran yang dapat menumbuh kembangkan kemampuan pemecahan masalah matematika siswa. Menurut Ansari ( 2009 : 84) “ Strategi Think Talk Write (TTW) diperkenalkan oleh Huinker \& Laughlin (1996) yang pada dasarnya dibangun melalui berfikir, berbicara, dan menulis. Strategi TTW ini mempunyai kelebihan yaitu pada tahap atau alur strategi TTW dalam suatu pembelajaran dimulai dari keterlibatan siswa dalam berfikir (bagaimana siswa memikirkan penyelesaian suatu masalah) atau berdialog dengan dirinya sendiri setelah proses membaca masalah, selanjutnya berbicara (bagaimana mengkomunikasikan hasil pemikirannya dalam diskusi) dan membagi ide (sharing) dengan temannya sebelum menulis. Suasana seperti ini lebih efektif jika dilakukan dalam kelompok heterogen dengan 3-5 siswa. Dalam kelompok ini siswa diminta membaca, membuat catatan kecil, menjelaskan, mendengarkan dan membagi ide bersama teman kemudian mengungkapkannya melalui tulisan.

Dari pernyataan di atas keterlibatan siswa dalam memikirkan masalah atau berdialog dengan dirinya sendiri sebelum mengkomunikasinnya kepada teman kelompoknya mebuat siswa lebih kritis dalam membaca masalah yang ada. Keterlibatan kelompok siswa yang mencapai 3-5 orang yang dipilih secara heterogen lebih memudahkan siswa untuk bertukar fikiran dalam memecahkan masalah. Semakin banyak teman untuk bertukar fikiran dalam memecahkan masalah matematika semakin sedikit kesalahan yang akan mereka buat. Dengan dipilihnya teman kelompok secara heterogen dengan jumlah 3-5 siswa menjadikan siswa lebih terpacu untuk saling bekerja sama dalam Terkait model pembelajaran tipe TTW dalam mengembangkan kemampuan pemecahan masalah matematika didukung oleh penelitian yang relevan yang dilakukan oleh Yuanari (2011) hasil penelitian menunjukkan bahwa terjadi peningkatan kemampuan pemecahan masalah siswa setelah mengikuti pembelajaran dengan model TTW.

Berdasarkan uraian di atas disimpulkan bahwa model pembelajaran TPS dan TTW merupakan dua model pembelajaran kooperatif yang dianggap dapat membangkitkan ketertarikan siswa terhadap materi matematika, membuat siswa lebih aktif, mendorong kerja sama antar siswa dalam mempelajari suatu materi,

Rahmadhani Siregar, Syafari. Perbandingan Kemampuan Pemecahan Masalah Matematis Siswa yang Belajar Menggunakan Model Pembelajaran Kooperatif Tipe Think Talk Write dan Think Pair Share di SMP Negeri 1 Tanjung Morawa. Jurnal Inspiratif, Vol 3. No. 1 April 2017 
sehingga dapat meningkatkan kemampuan pemecahan masalah siswa. Hal ini juga didasari oleh penelitian yang dilakukan Husna (2013) dan Yuanari (2011) telah diuraikan sebelumnya bahwa model pembelajaran kooperatif tipe TPS dan tipe TTW masing masing dapat mempengaruhi kemampuan pemecahan masalah siswa menjadi lebih tinggi.

Selain itu jika ditinjau dari masing-masing karakteristik yang dimiliki oleh kedua model tersebut seperti yang telah dipaparkan sebelumnya, kedua model ini sama sama menerapkan kerja sama dalam kelompok untuk dapat saling membantu dalam memahami materi pelajaran yang akan digunakan untuk menyelesaikan masalah matematika dengan maksimal. Di dalam pembelajaran kooperatif tipe TTW dengan Keterlibatan kelompok siswa yang mencapai 3-5 orang yang dipilih secara heterogen lebih memudahkan siswa untuk bertukar fikiran dalam memecahkan masalah. Semakin banyak teman untuk bertukar fikiran dalam memecahkan masalah matematika semakin sedikit kesalahan yang akan mereka buat. Hal ini memungkinkan setiap siswa secara individual akan memiliki keberhasilan lebih banyak jika dibandingkan dengan pembelajaran kooperatif tipe TPS. Pada pembelajaran kooperatif tipe TPS siswa dituntut berfikir lalu berbagi ide dalam menyelesaikan masalah matematika dengan pasangannya. Keterbatasan anggota kelompok membatasi mereka untuk bertukar fikiran dalam menyelesaikan masalah. secara tidak langsung mengurangi minat siswa dalam menyelesaikan permasalahan matematika yang diberi oleh guru.
Kurangnya minat siswa dan keterbatasan anggota kelompok dalam berbagi ide memungkinkan siswa akan mengalami keterbatasan dalam mengembangkan kemampuan pemecahan masalahnya.

Maka dalam penelitian ini peneliti ingin mengetahui dengan menggunakan model pembelajaran kooperatif tipe TTW dan TPS manakah yang dapat mempengaruhi kemampuan pemecahan masalah matematika siswa menjadi lebih tinggi.

\section{Metode Penelitian}

Dalam penelitian ini terdapat dua kelompok sampel yang diteliti, yaitu kelompok eksperimen 1 dan kelompok eksperimen 2. Metode yang digunakan dalam penelitian ini adalah metode kuasi eksperimen atau eksperimen semu, yaitu penelitian yang dimaksudkan untuk mengetahui ada tidaknya akibat dari sesuatu yang dikenakan pada subjek, dalam hal ini siswa, dan dikatakan eksperimen semu sebab kondisi-kondisi siswa tidak dapat dikontrol secara keseluruhan (Sugiyono, 2013: 114). Teknik pengambilan sampel dalam penelitian ini adalah cluster random sampling, yang berarti setiap kelas memiliki peluang yang sama untuk dijadikan sampel penelitian. Sampel yang terpilih yaitu siswa kelas VII-1 sebagai kelas eksperimen I menggunakan kooperatif tipe TTW (Think Talk Write) yang berjumlah 25 orang dan siswa kelas VII-2 sebagai kelas eksperimen II menggunakan kooperatif tipe TPS (Think Pair Share) sebanyak 26 orang. 


\section{Hasil Penelitian dan Pembahasan}

Setelah kedua kelas diberi perlakuan yang berbeda kemudian diberikan postes untuk mengetahui kemampuan pemecahan masalah matematik siswa. Soal yang dipakai adalah soal berbentuk uraian yang berjumlah 3 butir soal. Sebelum soal tersebut diberikan, dilakukan validasi soal kepada 3 orang ahli dan semua soal valid sehingga soal layak dipakai.

Dari hasil postes diperoleh rata-rata postes kelas eksperimen A dengan model pembelajaran kooperatif tipe TTW adalah 28,20 dan rata-rata postes kelas eksperimen B dengan model pembelajaran kooperatif tipe TPS adalah 25,27.

Dalam Penelitian ini instrument penilaian only posttest. Kedua kelas sampel diberikan perlakuan yang berbeda. Setelah diberi perlakuan yang berbeda pada kelas eksperimen A dan kelas eksperimen B, kemudian kedua kelas diberikan postes atau tes akhir untuk mengetahui kemampuan pemecahan masalah matematik siswa kelas eksperimen A dan kelas eksperimen B. Postes terdiri dari tiga butir soal yang mengandung aspek atau indikator pemecahan masalah, yaitu dimulai dari memahami masalah, membuat rencana penyelesaian, melaksanakan rencana penyelesaian, dan memeriksa kembali.

Dari hasil penelitian diperoleh nilai rata-rata postest kelas eksperimen A lebih tinggi dibandingkan kelas eksperimen B. Dimana kelas eksperimen A belajar dengan model pembelajaran TTW. Langkah langkah pada TTW yaitu Think (berfikir), Talk (berdiskusi), Write (menulis), pada model pembelajaran TTW tahapan berdiskusi yang melibatkan 3-5 orang yang dipilih secara heterogen lebih memudahkan siswa dalam untuk bertukar fikiran dalam memecahkan masalah. Semakin banyak teman untuk bertukar fikiran dalam memecahkan masalah matematika semakin sedikit kesalahan yang akan mereka buat. Hal ini memungkinkan setiap siswa secara individual akan memiliki keberhasilan lebih banyak jika dibandingkan dengan pembelajaran kooperatif tipe TPS.

Pada pembelajaran kooperatif tipe TPS siswa dituntut berfikir lalu berbagi ide dalam menyelesaikan masalah matematika dengan pasangannya. Keterbatasan anggota kelompok membatasi mereka untuk bertukar fikiran dalam menyelesaikan masalah. secara tidak langsung mengurangi minat siswa dalam menyelesaikan permasalahan matematika yang diberi oleh guru. Kurangnya minat siswa dan keterbatasan anggota kelompok dalam berbagi ide memungkinkan siswa akan mengalami keterbatasan dalam mengembangkan kemampuan pemecahan masalahnya.

Secara keseluruhan dari hasil postest yang ada diperoleh bahwa terdapat perbandingan kemampuan pemecahan masalah matematik siswa melalui pembelajaran kooperatif pada kelas eksperimen A yakni dengan model kooperatif tipe ThinkTalk-Write dengan kelas eksperimen B yakni dengan model kooperatif tipe Think-Pair-Share di Kelas VII SMP Negeri 1 Tanjung Morawa.

Berdasarkan fakta yang ditemukan peneliti seperti yang disebutkan diatas diperoleh bahwa siswa yang belajar dengan model kooperatif tipe Think Talk Write (TTW) memiliki kemampuan

Rahmadhani Siregar, Syafari. Perbandingan Kemampuan Pemecahan Masalah Matematis Siswa yang Belajar Menggunakan Model Pembelajaran Kooperatif Tipe Think Talk Write dan Think Pair Share di SMP Negeri 1 Tanjung Morawa. Jurnal Inspiratif, Vol 3. No. 1 April 2017 
pemecahan masalah yang lebih baik dibandingkan dengan siswa yang belajar dengan model kooperatif tipe Think-Pair-Share (TPS), hal ini dikarenakan pada proses pembelajaran TTW siswa dibagi ke dalam kelompok yang beranggotakan 5 orang, sehingga pada saat diskusi setiap siswa akan mengajukan pendapatnya masing-masing sehingga lebih mudah dalam menyelesaikan soal-soal. Sementara itu, siswa yang belajar dengan model kooperatif tipe TPS, siswa hanya dibentuk berpasangan yang terdiri dari 2 siswa yang mengakibatkan ide-ide yang diajukan siswa dalam memecahkan masalah lebih sedikit.

Dilihat dari sisi tingkat kemampuan pemecahan masalah matematik siswa, kedua kelas juga memiliki perbedaan yang signifikan. Tingkat kemampuan pemecahan masalah matematik siswa melalui pembelajaran TTW terdiri dari 10 siswa dengan kategori sangat tinggi, 8 siswa dengan kategori tinggi, 7 siswa dengan kategori sedang dan tidak ada siswa dengan kategori rendah dan sangat rendah. Sedangkan tingkat kemampuan pemecahan masalah matematik siswa melalui pembelajaranTPS terdiri dari 2 siswa dengan kategori sangat tinggi, 5 siswa dengan kategori tinggi, 16 siswa dengan kategori sedang, 2 siswa dengan kategori rendah dan 1 siswa dengan kategori sangat rendah. Berdasarkan fakta diatas siswa yang belajar dengan model kooperatif tipe Think Talk Write (TTW) memiliki tingkat kemampuan pemecahan masalah yang lebih baik dibandingkan dengan siswa yang belajar dengan model kooperatif tipe Think-Pair-Share (TPS). Hal itu bisa dilihat dari lebih banyaknya siswa yang tingkat kemampuan pemecahan masalah matematiknya berkategori sangat baik pada kelas TTW yakni 10 siswa dibandingkan dengan kelas TPS yang banyaknya siswa dengan tingkat kemampuan pemecahan masalah matematik berkategori sangat baik lebih sedikit yakni hanya 2 orang siswa.

Hasil penelitian ini sejalan dengan beberapa hasil penilitian terdahulu yaituFertilia (2014) "Perbandingan kemampuan representasi matematis siswa antara model pembelajaran TTW dan TPS". Berdasarkan hasil penelitian diperoleh rata-rata sampel kelas eksperimen I (menggunakan TTW) adalah 78,77 dan nilai rata-rata sampel kelas eksperimen 2 (menggunakan TPS) adalah 65,18. Hal ini menandakan bahwa kemampuan representasi matematis siswa dengan model pembelajaran TTW lebih tinggi daripada kemampuan representasi matematis siswa dengan model pembelajaran TPS.

Selain itu Suningsih (2014) "Eksperimentasi model pembelajaran kooperatif tipe TTW dan TPS pada persamaan garis lurus ditinjau dari karakteristik cara berpikir siswa SMP se-Kabupaten

Pringsewu.Berdasarkan hasil penelitian diperoleh rata-rata marginal kelas eksperimen I (menggunakan TTW) adalah 70,071 dan nilai rata-rata marginal kelas eksperimen 2 (menggunakan TPS) adalah 69,294. Hal ini menunjukkan bahwa prestasi belajar siswa ditinjau dari cara berpikir menggunakan model pembelajran kooperatif tipe TTW lebih baik daripada tipe TPS.

Rahmadhani Siregar, Syafari. Perbandingan Kemampuan Pemecahan Masalah Matematis Siswa yang Belajar Menggunakan Model Pembelajaran Kooperatif Tipe Think Talk Write dan Think Pair Share di SMP Negeri 1 Tanjung Morawa. Jurnal Inspiratif, Vol 3. No. 1 April 2017 


\section{Kesimpulan}

Berdasarkan hasil penelitian dan pengolahan data maka dapat ditarik kesimpulan sebagai berikut:

Kemampuan pemecahan masalah matematik siswa melalui pembelajaran kooperatif tipe ThinkTalk-Write lebih tinggi daripada model pembelajaran pembelajaran kooperatif tipe Think-Pair-Share di Kelas VII SMP Negeri 1 Tanjung Morawa dengan rata-rata nilai kemampuan pemecahan masalah matematik berturut-turut adalah 28,20 dan 25,27. Hal ini juga dibuktikan dari hasil pengujian hipotesis pada taraf signifikansi $\alpha=0,05$ dan $\mathrm{dk}=49$ dengan $t_{\text {hitung }}=3,66$ dan $t_{\text {tabel }}=1,666$.

\section{Saran}

Berdasarkan hasil penelitian ini maka saran yang dapat peneliti berikan adalah:

1. Kepada guru matematika jika memilih antara model TTW dan TPS, lebih baik menggunakan model TTW dibandingkan model TPS untuk meningkatkan kemampuan pemecahan masalah siswa pada materi bangun datar persegi panjang dan segiempat.

2. Bagi guru matematika jika memilih antara model TTW dan TPS, lebih baik menggunakn model TTW dibandingkan TPS karena kelas yang diajar dengan TTW tuntas sedangkan kelas yang diajar dengan TPS tidak tuntas

3. Bagi peneliti berikutnya agar mengadakan penelitian yang sama dengan materi ataupun tingkatan kelas yang berbeda sehingga hasil penelitian dapat berguna bagi kemajuan pendidikan

pendidikan matematika.

\section{DAFTAR PUSTAKA}

Abdurrahman, Mulyono., (2012), Anak Berkesulitan Belajar: Teori, Diagnosis, dan Remediasinya, Rineka Cipta, Jakarta.

Ansari, Bansu., (2009), Komunikasi Matematik:Konsep dan Aplikasi, Pena, Banda Aceh.

Huda, Miftahul., (2014), ModelModel Pengajaran dan Pembelajaran, Pustaka Pelajar, Yogyakarta.

Husna, dkk., (2013), Peningkatan Kemampuan Pemecahan Masalah Dan Komunikasi Matematis Siswa Sekolah Menegah Pertama Melalui Model Pembelajaran Kooperatif Tipe Think-PairShare (TPS). Jurnal Peluang. Vol.1, No.4. ISSN: 23025158

Isjoni., (2009), Pembelajaran kooperatif, Pustaka Pelajar, Yogyakarta.

Istarani., (2011), 58 Model Pembelajaran Inovatif, Media Pustaka, Medan.

Lie, Anita., (2010), Cooperatif Learning, Grasindo, Jakarta.

Noor, Aisjah Juliani, dan Norlaila., (2014), Kemampuan Pemecahan Masalah Siswa Dalam Pembelajaran Matematika Menggunakan Model Cooperative Script. Jurnal Pendidikan Matematika. Vol. 2, No. 3.

Rahmadhani Siregar, Syafari. Perbandingan Kemampuan Pemecahan Masalah Matematis Siswa yang Belajar Menggunakan Model Pembelajaran Kooperatif Tipe Think Talk Write dan Think Pair Share di SMP Negeri 1 Tanjung Morawa. Jurnal Inspiratif, Vol 3. No. 1 April 2017 
Polya, G., (1973), How To Solve It, A New Aspect of Mathematical Method, Princeton University Press, Princeton.

Rusman., (2014), Model-model Pembelajaran

(Mengembangkan

Profesionalisme Guru), Rajawali Press, Jakarta.

Slameto., (2010), Belajar dan Faktor-Faktor yang Mempengaruhinya, Rineka Cipta, Jakarta.

Sugiyono., (2011), Statistika untuk Penelitian, Alfabeta, Bandung.

Sanjaya, W., (2009), Strategi Pembelajaran Berorientasi Standar Proses Pendidikan, Kencana, Jakarta

Suprijono, Agus., (2012), Cooperative Learning: Teori \& Aplikasi PAIKEM, PT Pustaka Pelajar, Yogyakarta.

Suharsimi, Arikunto., (2013), Prosedur Penelitian Suatu Pendekatan Praktik, Rineka Cipta, Jakarta.

Sudjana., (2005), Metoda Statistika, Tarsito, Bandung.

Trianto., (2011), Mendesain Model Pembelajaran InovatifProgresif, Kencana, Prenada Media Group, Jakarta.

Zakaria, E., Chin, L. C., dan Daud, Y., (2010), The Effects of Cooperative Learning on Students' Mathematics Achievement and Attitude towards Mathematics, Journal of Social Sciences, Vol. 6 No.2, 272-275
Zulkarnain.2015. Type Cooperatif Learning Initiatad by Story Questions toward the Ability to Complete Story Questions in Math of Class VII Student of Junior High School (SMP Negeri 1 dan MTSn) in Pangean District, Kuantan Singingi Regency. Mediteranean journal of Social Science 6(3) :102-109. ISSN 20392117 